\title{
Serum vitamin D level variation in SIRS, sepsis and septic shock
}

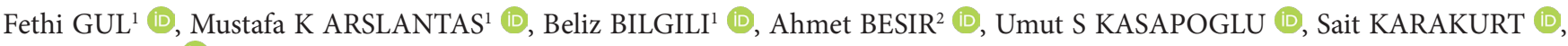 \\ Ismail CINEL ${ }^{1}$ (iD \\ 1 Division of Critical Care Medicine, Department of Anesthesiology and Reanimation, Marmara University Pendik Training and Research Hospital, \\ Istanbul, Turkey \\ 2 Department of Anesthesiology and Reanimation, School of Medicine, Karadeniz Technical University, Trabzon, Turkey \\ 3 Department of Pulmonary Diseases and Critical Care, School of Medicine, Marmara University Pendik Training and Research Hospital, Istanbul, \\ Turkey \\ Corresponding Author: Ismail CINEL \\ E-mail: cinelismail@yahoo.com
}

Submitted: $20.07 .2019 \quad$ Accepted: 03.09.2019

\begin{abstract}
Objectives: Vitamin D has potent immunomodulatory effects with the capability of acting as an autocrine and paracrine agent, and inhibits inflammatory signaling. In this study, our aim was to evaluate the relationship between vitamin D levels in systemic inflammatory response syndrome (SIRS), sepsis and, septic shock patients and outcomes.

Patients and Methods: A total of 45 patients whose vitamin D levels were measured within the first 48 hours of Intensive Care Unit (ICU) admission and 20 healthy controls were studied prospectively. The patients were grouped as, SIRS (Group-I,n=10), sepsis (Group-II,n=25), septic shock (Group-III,n=10) and healthy subjects (Group-IV,n=20). Serum vitamin D levels were categorized as a deficiency $(\leq 15 \mathrm{ng} / \mathrm{mL})$, insufficiency $(16-29 \mathrm{ng} / \mathrm{mL})$ and sufficiency $(\geq 30 \mathrm{ng} / \mathrm{mL})$. Demographic characteristics, Acute Physiology and Chronic Health Assessment II (APACHE-II) scores, and biochemical parameters were noted.

Results: Vitamin D levels were significantly lower in all study groups compared to the control group $(\mathrm{p}<0.01)$, but were similar among the study groups. The hospital and ICU length of stay (LOS), and biochemical parameters were similar among the study groups. The mortality rates were $40 \%$ in Group I, $57 \%$ in Group II, and $80 \%$ in Group III.

Conclusion: In our study patients with SIRS, sepsis and septic shock had lower serum 25-OH vitamin D levels compared to the control group. Our results are in line with the literature that supports a relationship between vitamin D deficiency and inflammation.

Keywords: Critically ill patients, Vitamin D, Sepsis, SIRS
\end{abstract}

\section{INTRODUCTION}

Sepsis was defined as a clinical syndrome by the presence or suspected of both infection and systemic inflammatory response combined with organ injury in the 2001 by International Sepsis Definitions Conference [1]. The incidence of sepsis, which is one of the most important reasons for admission to the intensive care unit (ICU), has increased significantly in the last 20 years. However; although the positive effects of advances and awareness campaigns in the management of sepsis provide an increase in survival, sepsis is still the most important cause of mortality and morbidity in ICU [2].

A large amount of vitamin $\mathrm{D}$, which is fat-soluble, is produced on the skin by sunlight and a limited amount is obtained from the diet. It plays an important role in the regulation of bone and calcium metabolism. Vitamin D is stored in fat cells and is converted to hydroxyvitamin D3, the so-called circulating form in the liver. Hydroxyvitamin D3 is mainly converted to calcitriol, the active metabolite in the kidneys $[3,4]$.
Vitamin D metabolites have significant pleiotropic effects on innate and adaptive immune system cells. The calcitriol, biologically active metabolite of vitamin $\mathrm{D}$, increases the production of cathelicidin and defensin and thus plays a role in the innate immune system. In addition, it exerts its effects on the adaptive immune system via vitamin $\mathrm{D}$ receptors on monocytes, $\mathrm{T}$, and $\mathrm{B}$ cells. Vitamin $\mathrm{D}$ also affects the proliferation and differentiation of $\mathrm{T}$ and $\mathrm{B}$ cells and modulates immunoglobulin production [5-7].

It is assumed that more than 1 billion people worldwide have vitamin $\mathrm{D}$ deficiency. It was well-established that vitamin $\mathrm{D}$ deficiency is a well-known cause of musculoskeletal disorders. Recent studies have shown that vitamin D deficiency may play a role in the pathogenesis of infection, immunological, neurological, cardiovascular and respiratory diseases [4,6-8].

Its deficiency is frequently observed in critically ill patients and has been shown to be associated with increased mortality and prolonged hospital stay. Similarly, the deficiency was reported to

How to cite this article: Gul F, Arslantas MK, Bilgili B, et al. Serum vitamin D level variation in SIRS, sepsis and septic shock. 2019 ; 32: 102-106. doi: $10.5472 /$ marumj.637569 
be a risk factor for mortality in critically ill patients with sepsis [6,8-11].

In this study, we aimed to evaluate the relationship between the severity of sepsis and serum $25-\mathrm{OH}$ vitamin $\mathrm{D}$ levels and its effect on survival in critically ill patients.

\section{PATIENTS and METHODS}

\section{Study Design}

A prospective cohort study was performed between January 2015 and July 2015 in the ICU of the Marmara University Training and Research Hospital. A total of 45 critically ill patients and 20 voluntary healthy volunteers were included in the study. The study protocol was approved by the Institutional Ethics Committee and was in compliance with the principles of the Declaration of Helsinki. The informed written consent form was obtained from patients and healthy volunteers.

Demographic data of the patients, Acute Physiology and Chronic Health Assessment II (APACHE II) scores, length of intensive care and hospital stay, serum $25-\mathrm{OH}$ vitamin $\mathrm{D}$, C-reactive protein (CRP), procalcitonin, parathyroid hormone $(\mathrm{PTH})$ levels, hemogram, and biochemical parameters were recorded.

The patients were divided into groups as, systemic inflammatory response syndrome (SIRS) (Group I, $n=10$ ), sepsis (Group II, $\mathrm{n}=25$ ), septic shock (Group III, $\mathrm{n}=10$ ) and voluntary healthy subjects (Group IV, $\mathrm{n}=20$ ) for the control group.

\section{Definitions}

The serum $25-\mathrm{OH}$ vitamin D vitamin D levels were categorized as deficiency $(\leq 20 \mathrm{ng} / \mathrm{mL})$, insufficiency $(20-29 \mathrm{ng} / \mathrm{mL})$ and sufficiency $(\geq 30 \mathrm{ng} / \mathrm{mL})$ in accordance with the guidelines of the Endocrine Society. Also, the serum 25-OH vitamin D level $\leq$ $10 \mathrm{ng} / \mathrm{mL}$ were defined as very severe vitamin D deficiency [12].

Systemic inflammatory response syndrome; is a systemic inflammatory response to various clinical conditions. Body temperature $>38^{\circ} \mathrm{C}$ or $<36^{\circ} \mathrm{C}$, heart rate $>90 /$ min, respiratory rate $>20 / \mathrm{min}$ or $\mathrm{PaCO} 2<32 \mathrm{mmHg}$, with the presence of at least two of the followings; leukocyte count $>12000 / \mathrm{mm} 3$ or $<4000 /$ $\mathrm{mm} 3$ or $>10 \%$ of the young neutrophil [1].

According to the 2001 International Sepsis Definitions Conference, sepsis patients were defined as a clinical syndrome of systemic inflammatory response together with infection. Septic shock patients were defined as persistent arterial hypotension (systolic arterial pressure $<90 \mathrm{mmHg}$, mean arterial pressure $<60 \mathrm{mmHg}$, or blood pressure decreased to $40 \mathrm{mmHg}$ from normal baseline value) which cannot be explained for other reasons and is unresponsive to fluid resuscitation [1]

\section{Clinical Data}

25-OH vitamin $\mathrm{D}$ levels and other biochemical parameters of the patients were measured within 48 hours after they were admitted to the ICU. Serum 25-OH vitamin D levels were determined by high - performance liquid chromatography method (HPLC; Recipe Chemicals, Munich, Germany), serum CRP level by BN II nephelometer method (Siemens, Erlangen, Germany), serum procalcitonin levels by electrochemiluminescence immunoassay method (Roche Cobas e411; Roche Diagnostics, Indianapolis, USA), serum PTH level was measured by chemiluminescence immunoassay method (Modular Analytics E170; Roche Diagnostics, Mannheim, Germany) and other biochemical values were measured by enzymatic colorimetric method (Roche Diagnostics, Indianapolis, USA). The complete blood count parameters were measured by Coulter STKS hematological analyzer method (Beckman Coulter Cooperation, Miami, FL, USA).

\section{Statistical Analysis}

In this study, data showing normal distribution were given as mean \pm standard deviation, data not showing normal distribution were given as median (min-max) values as numbers. The OneWay Anova test was used for the analysis of distributed data. The results were evaluated with a 95\% confidence interval, and $\mathrm{p}<0.05$ was considered as the level of statistical significance. Statistical Package for Social Sciences (SPSS) for Windows 21.0 was used for statistical analysis.

\section{RESULTS}

Sixty-five patients were enrolled into the study. The patients were grouped as, SIRS (Group I, n=10), sepsis (Group II, $n=25$ ), septic shock (Group III, $\mathrm{n}=10$ ) and healthy volunteers (Group IV, $n=20$ ) for the control group. Patients with SIRS, sepsis, and the septic shock had significantly lower $25-\mathrm{OH}$ vitamin $\mathrm{D}$ levels than healthy volunteers $(\mathrm{p}=0.001)$ (Figure 1 ). The baseline demographic characteristics, 25-OHD levels, and other clinical parameters of patients and healthy volunteers are given in Table I. The clinical and laboratory findings of patients are presented in Table II.

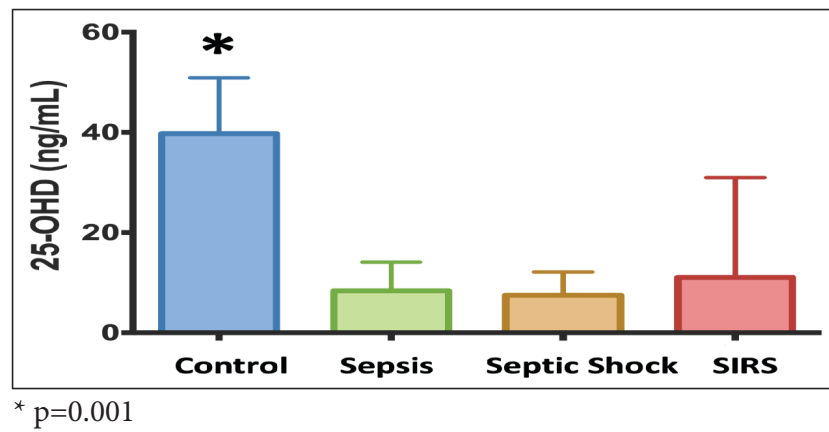

Figure 1. Serum 25-OH vitamin D levels in patients and healthy volunteers. 
Table I. The baseline demographic characteristics, 25-OHD levels and other clinical parameters of patients and healthy volunteers

\begin{tabular}{|c|c|c|c|c|c|}
\hline & SIRS & Sepsis & $\begin{array}{l}\text { Septic } \\
\text { Shock }\end{array}$ & $\begin{array}{l}\text { Healty } \\
\text { Control }\end{array}$ & \\
\hline & $\begin{array}{l}\text { Mean } \pm \\
\text { SD }\end{array}$ & Mean \pm SD & Mean \pm SD & Mean \pm SD & \\
\hline Age (years) & $\begin{array}{l}62.38 \pm \\
16.69\end{array}$ & $\begin{array}{l}55.74 \pm \\
17.81\end{array}$ & $\begin{array}{l}60.70 \pm \\
11.56\end{array}$ & $44.81 \pm 15.03$ & 0.016 \\
\hline $\begin{array}{l}\text { APACHE-II } \\
\text { score }\end{array}$ & $\begin{array}{l}14.90 \pm \\
5.15\end{array}$ & $\begin{array}{l}22.21 \pm \\
8.54\end{array}$ & $\begin{array}{l}22.40 \pm \\
5.04\end{array}$ & N/A & 0.03 \\
\hline $\begin{array}{l}\text { ICU LOS } \\
\text { (days) }\end{array}$ & $\begin{array}{l}13.80 \pm \\
19.26\end{array}$ & $\begin{array}{l}26.52 \pm \\
54.46\end{array}$ & $\begin{array}{l}16.90 \pm \\
22.90\end{array}$ & N/A & 0.69 \\
\hline $\begin{array}{l}\text { Hospital } \\
\text { LOS (days) }\end{array}$ & $\begin{array}{l}18.50 \pm \\
18.77\end{array}$ & $\begin{array}{l}31.39 \pm \\
60.60\end{array}$ & $\begin{array}{l}18.60 \\
\pm .22 .40\end{array}$ & N/A & 0.67 \\
\hline $\begin{array}{l}25-\mathrm{OHD} \\
(\mathrm{ng} / \mathrm{mL})\end{array}$ & $\begin{array}{l}8.39 \pm \\
5.70\end{array}$ & $7.49 \pm 4.64$ & $5.16 \pm 3.97$ & $39.77 \pm 11.13$ & 0.001 \\
\hline
\end{tabular}

25-OHD: 25-hydroxy vitamin D, ICU LOS: Intensive care unit length of stay, LOS: length of stay, APACHE II: Acute Physiology and Chronic Health Evaluation II, N/A: Not Applicable, SD: Standard Deviation

Table II. The clinical and laboratory findings of the patients

\begin{tabular}{|c|c|c|c|c|}
\hline & $\begin{array}{l}\text { SIRS } \\
\text { Mean } \pm \text { SD }\end{array}$ & $\begin{array}{l}\text { Sepsis } \\
\text { Mean } \pm \text { SD }\end{array}$ & $\begin{array}{l}\text { Septic Shock } \\
\text { Mean } \pm \text { SD }\end{array}$ & $\mathrm{p}$ value \\
\hline $\mathrm{WBC}\left(/ \mathrm{mm}^{3}\right)$ & $\begin{array}{l}14229 \pm \\
7013\end{array}$ & $14434 \pm 7201$ & $13127 \pm 7073$ & 0.09 \\
\hline $\begin{array}{l}\text { 25-OHD (ng/ } \\
\mathrm{mL})\end{array}$ & $8.39 \pm 5.70$ & $7.49 \pm 4.64$ & $5.16 \pm 3.97$ & 0.19 \\
\hline $\begin{array}{l}\text { Albumin }(\mathrm{g} / \\
\mathrm{dL})\end{array}$ & $2.57 \pm 0.81$ & $3.42 \pm 3.65$ & $2.22 \pm 0.60$ & 0.66 \\
\hline BUN (mg/dL) & $\begin{array}{l}30.30 \pm \\
28.22\end{array}$ & $28.57 \pm 16.83$ & $42.55 \pm 29.10$ & 0.44 \\
\hline $\begin{array}{l}\text { Creatinine } \\
(\mathrm{mg} / \mathrm{dL})\end{array}$ & $1.22 \pm 1.24$ & $1.02 \pm 0.65$ & $1.62 \pm 1.23$ & 0.25 \\
\hline $\begin{array}{l}\text { Glucose }(\mathrm{mg} / \\
\mathrm{dL})\end{array}$ & $\begin{array}{l}143.50 \pm \\
55.08\end{array}$ & $125.61 \pm 26.32$ & $166.73 \pm 60.51$ & 0.05 \\
\hline $\begin{array}{l}\text { Calcium (mg/ } \\
\text { dL) }\end{array}$ & $7.66 \pm 1.32$ & $8.13 \pm 0.95$ & $7.68 \pm 1.18$ & 0.40 \\
\hline $\begin{array}{l}\text { Parathormone } \\
(\mathrm{pg} / \mathrm{mL})\end{array}$ & $\begin{array}{l}78.45 \pm \\
66.36\end{array}$ & $110.44 \pm 123.20$ & $78.33 \pm 108.84$ & 0.63 \\
\hline $\mathrm{CRP}(\mathrm{mg} / \mathrm{L})$ & $\begin{array}{l}126.72 \pm \\
66.88\end{array}$ & $156.27 \pm 106.39$ & $184.79 \pm 119.07$ & 0.44 \\
\hline $\begin{array}{l}\text { Procalcitonin } \\
(\mathrm{ng} / \mathrm{mL})\end{array}$ & $1.96 \pm 2.39$ & $12.51 \pm 27.44$ & $5.09 \pm 9.54$ & 0.35 \\
\hline $\begin{array}{l}\text { Phosphorus } \\
\text { (mg/dL) }\end{array}$ & $2.82 \pm 0.97$ & $3.07 \pm 1.31$ & $3.52 \pm 1.50$ & 0.45 \\
\hline
\end{tabular}

25-OHD: 25-hydroxy vitamin D, WBC: White Blood Cells, BUN: Blood Urea Nitrogen, CRP: C-reactive Protein, SD: Standard Deviation

Patient's baseline laboratory parameters at ICU admission, ICU lenght of stay (LOS), and hospital LOS were similar in patients' groups. We found lower serum 25-OH vitamin D levels in sepsis and septic shock patients compared to patients who had SIRS but without a statistical significance $(\mathrm{p}=0.19)$. The mortality rates were $40 \%$ in Group I, 57 \% in Group II, and 80\% in Group III. In addition to this, serum $25-\mathrm{OH}$ vitamin D levels were lower in non-survivor patients compared with the survivors $(6.9 \pm 5.3$ vs. $7.4 \pm 3.6)$, but without a statistical significance $(\mathrm{p}=0.71)$.

\section{DISCUSSION}

In the present study, we evaluated the relationship between vitamin D levels in SIRS, sepsis, and septic shock patients and outcomes. The main finding of this study showed that the serum $25-\mathrm{OH}$ vitamin D levels were significantly lower in all study groups compared to the control group. In addition, vitamin $\mathrm{D}$ levels were found lower in non-survivor patients, even if it was not statistically significant. The hospital and ICU LOS, biochemical parameters were similar among the study groups.

Vitamin D is a fat-soluble steroid hormone, and it has a very important role in bone health, calcium homeostasis and also maintaining the optimal function of many organ systems $[7,8]$. Various clinical studies emphasize deficiency is a major healthcare problem worldwide and has a crucial role in some disease pathogenesis such as musculoskeletal diseases. Also, recent studies have shown that vitamin D deficiency is associated with systemic inflammation, infection, cancer, immunological, neurological, cardiovascular, and respiratory diseases $[8,13]$. Furthermore, the correlation between vitamin D deficiency and increased mortality has been shown in the general population $[14,15]$. Melamed et al., showed that lower serum vitamin D levels were associated with higher mortality in the general population [14]. Also, clinical studies and meta-analysis on patients with chronic kidney diseases have shown that higher serum vitamin D levels and also vitamin D supplementation were associated with improved survival $[15,16]$.

Vitamin D deficiency in critically ill patients has been well established [7]. The prevalence of low vitamin D concentrations was more than $90 \%$ among critically ill patients and higher than in patients who were hospitalized in non-critical units [17]. Recently, published studies and meta-analysis emphasized the association between vitamin D deficiency and mortality in critically ill patients [17-20]. There was a 1.81-fold higher risk of death in critically ill patients with vitamin D deficiency [21]. Furthermore, vitamin D deficiency has been associated with longer hospital stay and ICU LOS, increased risk of ICUacquired infections, and sepsis [7,17-19,21,22]. In our study, we found that $95.5 \%$ of patients had vitamin D deficiency ( $\leq$ $20 \mathrm{ng} / \mathrm{mL}$ ) on admission to the ICU. We found that vitamin D levels were lower in non-survivor patients compared with the survivors, but it was not statistically significant.

Vitamin D deficiency is associated with an increased risk of infectious diseases and sepsis. It was considered a significant prognostic factor for mortality in patients with sepsis $[6,7,11,17,20,23,24]$. Its deficiency affects the development of sepsis with several mechanisms that includes adaptive and innate immune modulation, suppression of the inflammatory response, enhanced phagocytosis and chemotaxis, and increased production of antimicrobial peptide $\beta$-defensins and cathelicidins [17,25-28]. It was shown that high levels of serum $25-\mathrm{OH}$ vitamin $\mathrm{D}$ ( $38 \mathrm{ng} / \mathrm{mL}$ or greater) decreased the incidences of urinary tract infections [25]. However, the association 
between respiratory tract infections (RTI) and serum vitamin $\mathrm{D}$ levels is controversial. Some observational and case-control studies revealed that hospital admission due to RTI is associated with lower vitamin D serum levels [26,27]. In contrast to this, some studies claimed that there was no relationship between vitamin D status and RTI $[28,29]$. In a prospective cohort study, including 461 patients with suspected sepsis, no statistically significant difference was found in $1,25(\mathrm{OH})$ D levels between those with or without infections [30].

Also, there is a correlation between serum levels of vitamin $\mathrm{D}$ and the severity of sepsis and still a contributing factor of organ dysfunction. Patients with septic shock had a lower serum level of vitamin D compared with septic patients without organ dysfunction $\{29,30]$. Jeng et al., found that there were no significant differences in serum levels of vitamin $\mathrm{D}$ between patients with sepsis and critically ill patients [31]. In the present study, we found that critically ill subjects had significantly lower plasma serum levels of vitamin D compared with healthy controls even if low serum levels of vitamin D seen in septic shock, sepsis and SIRS patients but the levels were comparable among the study groups.

\section{Limitations}

The mean 25-OH vitamin D proportion of deficiency does not vary across different ages. Therefore, we did not take the age difference between the groups into account. We also did not pay attention to the comorbidities and malnutrition, which are important causes of vitamin $\mathrm{D}$ deficiency. In addition to this, pre-illness vitamin D levels were unknown in study groups.

\section{Conclusion}

Vitamin D deficiency is commonly seen in critically ill patients. Although, it is not an independent factor for mortality, it might be related to worse clinical status during ICU stay. In our study, we found that the serum $25-\mathrm{OH}$ vitamin D level in ICU patients with SIRS, sepsis and septic shock were lower than healthy individuals, but the levels of serum vitamin $\mathrm{D}$ were similar among the study groups. Our results showed that the severity of the disease had no effect on the serum levels of vitamin D. Thus, inflammation mainly may cause alterations in vitamin D metabolisms. The new trials are needed to determine the role of vitamin $\mathrm{D}$ before or during critical illnesses, and to investigate whether it can improve clinical outcomes.

Disclosure: The authors declare that there is no conflict of interest regarding the publication of this article.

\section{REFERENCES}

[1] Levy MM, Fink MP, Marshall JC, et al. 2001 SCCM/ESICM/ ACCP/ATS/SIS International Sepsis Definitions Conference. Crit Care Med 2003;31:1250-6.

[2] Gul F, Arslantas MK, Cinel I, Kumar A. Changing definitions of sepsis. Turk J Anaesthesiol Reanim 2017;45:129-38. doi: 10.5152/TJAR.2017.93753.
[3] Atalan HK, Gucyetmez B. Serum vitamin D level at ICU admission and mortality. Turk J Anaesthesiol Reanim 2017;45:193-6. doi: 10.5152/TJAR.2017.60234.

[4] Moraes RB, Friedman G, Wawrzeniak IC, et al. Vitamin D deficiency is independently associated with mortality among critically ill patients. Clinics 2015;70:326-32. doi: 10.6061/ clinics/2015(05)04

[5] Kempker JA, Han JE, Tangpricha V, Ziegler TR, Martin GS. Vitamin D and sepsis: An emerging relationship. Dermatoendocrinol 2012;4:101-8. doi: 10.4161/derm.19859.

[6] Parekh D, Patel JM, Scott A, et al. Vitamin D deficiency in human and murine sepsis. Crit Care Med 2017;45:282-9. doi: 10.1097/CCM.000.000.0000002095.

[7] Rech MA, Hunsaker T, Rodriguez J. Deficiency in 25-hydroxyvitamin D and 30-day mortality in patients with severe sepsis and septic shock. Am J Crit Care 2014;23:e72-9. doi: 10.4037/ajcc2014723.

[8] Amrein K, Christopher KB, McNally JD. Understanding vitamin $\mathrm{D}$ deficiency in intensive care patients. Intensive Care Med 2015;41:1961-4. doi: 10.1007/s00134.015.3937-4.

[9] Moromizato $\mathrm{T}$, Litonjua AA, Braun AB, Gibbons FK, Giovannucci E, Christopher KB. Association of low serum 25-hydroxyvitamin D levels and sepsis in the critically ill. Crit Care Med 2014;42:97-107. doi: 10.1097/ CCM.0b013e31829eb7af.

[10] Barnett N, Zhao Z, Koyama T, et al. Vitamin D deficiency and risk of acute lung injury in severe sepsis and severe trauma: a case-control study. Ann Intensive Care 2014;4:5. doi: 10.1186/2110-5820-4-5

[11] Mirijello A, Tosoni A, Zaccone V, et al. MEDS score and vitamin D status are independent predictors of mortality in a cohort of Internal Medicine patients with microbiological identified sepsis. Eur Rev Med Pharmacol Sci 2019;23:403343. doi: 10.26355/eurrev_201905_17834.

[12] Holick MF, Binkley NC, Bischoff-Ferrari HA, G, et al. Evaluation, treatment, and prevention of vitamin D deficiency: an Endocrine Society clinical practice guideline. J Clin Endocrinol Metab 2011;96:1911-30. doi: 10.1210/ jc.2011-0385.

[13] Gois PHF, Ferreira D, Olenski S, Seguro AC. Vitamin D and infectious diseases: Simple Bystander or Contributing Factor? Nutrients 2017;9. doi: 10.3390/nu9070651.

[14] Melamed ML, Michos ED, Post W, Astor B. 25-hydroxyvitamin $\mathrm{D}$ levels and the risk of mortality in the general population. Arch Intern Med 2008;168:1629-37. doi: 10.1001/ archinte.168.15.1629.

[15] Pilz S, Iodice S, Zittermann A, Grant WB, Gandini S. Vitamin $\mathrm{D}$ status and mortality risk in CKD: a meta-analysis of prospective studies. Am J Kidney Dis 2011;58:374-82. doi: 10.1053/j.ajkd.2011.03.020.

[16] Teng M, Wolf M, Ofsthun MN, et al. Activated injectable vitamin $\mathrm{D}$ and hemodialysis survival: a historical cohort study. J Am Soc Nephrol 2005;16:1115-25. doi: 10.1681/ ASN.200.407.0573 
[17] Azim A, Ahmed A, Yadav S, et al. Prevalence of vitamin $\mathrm{D}$ deficiency in critically ill patients and its influence on outcome: experience from a tertiary care centre in North India (an observational study). J Intensive Care 2013;1:14. doi: 10.1186/2052-0492-1-14.

[18] Alves FS, Freitas FG, Bafi AT, Azevedo LC, Machado FR. Serum concentrations of vitamin D and organ dysfunction in patients with severe sepsis and septic shock. Rev Bras Ter Intensiva 2015;27:376-82. doi: 10.5935/0103-507X.20150063

[19] de Haan K, Groeneveld AB, de Geus HR, Egal M, Struijs A. Vitamin D deficiency as a risk factor for infection, sepsis and mortality in the critically ill: systematic review and meta-analysis. Crit Care 2014;18:660. doi: 10.1186/ s13054.014.0660-4

[20] Sanaie S, Mahmoodpoor A, Hamishehkar H, Fattahi S, Soleymani S, Faramarzi E. The relationship of serum vitamin $\mathrm{D}$ level with the outcome in surgical intensive care unit patients. Iran J Pharm Res 2019;18:1052-9. doi: 10.22037/ ijpr.2019.110.0658

[21] McKinney JD, Bailey BA, Garrett LH, Peiris P, Manning T, Peiris AN. Relationship between vitamin D status and ICU outcomes in veterans. J Am Med Dir Assoc 2011;12:208-11. doi: 10.1016/j.jamda.2010.04.004.

[22] Zhou W, Mao S, Wu L, Yu J. Association Between Vitamin D Status and Sepsis. Clin Lab 2018;64:451-60. doi: 10.7754/Clin. Lab.2017.170919.

[23] Upala S, Sanguankeo A, Permpalung N. Significant association between vitamin $\mathrm{D}$ deficiency and sepsis: a systematic review and meta-analysis. BMC Anesthesiol 2015;15:84. doi: 10.1186/ s12871.015.0063-3.

[24] Shojaei M, Sabzeghabaei A, Valaei Barhagh H, Soltani S. The Correlation between serum level of Vitamin D and outcome of sepsis patients; a cross-sectional study. Arch Acad Emerg Med 2019;7:e1.

[25] De Pascale G, Vallecoccia MS, Schiattarella A, et al. Clinical and microbiological outcome in septic patients with extremely low 25-hydroxyvitamin D levels at initiation of critical care. Clin Microbiol Infect 2016;22:456 e7 - e13. doi: 10.1016/j. cmi.2015.12.015.

[26] Amrein K, Zajic P, Schnedl C, et al. Vitamin D status and its association with season, hospital and sepsis mortality in critical illness. Crit Care 2014;18:R47. doi: 10.1186/cc13790.

[27] Kempker JA, Tangpricha V, Ziegler TR, Martin GS. Vitamin $\mathrm{D}$ in sepsis: from basic science to clinical impact. Crit Care 2012;16:316. doi: 10.1186/cc11252.

[28] Moller S, Laigaard F, Olgaard K, Hemmingsen C. Effect of 1,25-dihydroxy-vitamin D3 in experimental sepsis. Int J Med Sci 2007;4:190-5.

[29] Ginde AA, Camargo CA, Jr., Shapiro NI. Vitamin D insufficiency and sepsis severity in emergency department patients with suspected infection. Acad Emerg Med 2011;18:551-4. doi: 10.1111/j.1553-2712.2011.01047.x.

[30] Olejarova M, Dobisova A, Suchankova M, Tibenska E, Szaboova K, Koutun J, et al. Vitamin D deficiency - a potential risk factor for sepsis development, correlation with inflammatory markers, SOFA score and higher early mortality risk in sepsis. Bratisl Lek Listy 2019;120:284-90. doi: 10.4149/ BLL_2019_040.

[31] Jeng L, Yamshchikov AV, Judd SE, Blumberg HM, Martin GS, Ziegler TR, et al. Alterations in vitamin D status and antimicrobial peptide levels in patients in the intensive care unit with sepsis. J Transl Med 2009;7:28. doi: 10.1186/1479-58767-28. 